УДК 579.61:616.3

DOI 10.11603/2311-9624.2019.3.10571

\author{
(М. Ю. Гончарук-Хомин ${ }^{1}$, С. С. Цуперяк ${ }^{1}$, Н. І. Мельничук ${ }^{1}$, Х. В. Погорецька ${ }^{2}$, \\ Л. О. Пацкань² \\ ДВНЗ «Ужгородський національний університет» ${ }^{1}$ \\ Тернопільський національний медичний університет імені І. Я. Горбачевського МОз України른 \\ myroslav.goncharuk-khomyn@uzhnu.edu.ua
}

\title{
Оцінка кількісних змін мікробіологічного профілю зубного нальоту з ділянки зубоясенної боріздки у пацієнтів із І стадією пародонтиту
}

\section{ІНФОРМАЦІЯ}

Надійшла до редакціï/Received: 03.09.2019 p.

Ключові слова: пародонтит; пародонтопатогени; лабораторний аналіз.

\section{АНОТАЦІЯ}

Резюме. Виникнення пародонтиту доказово асоційоване із впливом специфічних видів мікроорганізмів, категоризованих у відповідні комплекси, проте характер клінічного перебігу патології та ефективність лікування визначають складною взаємодією між патогенетичними факторами та індивідуальними генетичними, імунологічними та бактеріологічними пацієнтасоційованими параметрами.

Мета дослідження - встановити середні показники кількості основних пародонтопатогенів у складі мазків зубного нальоту в пацієнтів із І стадією пародонтиту.

Матеріали і методи. У ході реалізації поставленої мети були сформовані дослідна та контрольна групи осіб. До складу дослідної групи було включено 19 осіб із І стадією пародонтиту, до складу контрольної - 17 осіб без клінічно зареєстрованих ознак ураження тканин пародонта. Оцінку стадії пародонтиту проводили згідно 3 рекомендаціями American Academy of Periodontology від 2017 р. Визначення кількісного складу цільових пародонтопатогенів в умовах норми та I стадії розвитку пародонтиту проводили із застосуванням аналізу «Пародонтоскрин», котрий виконували в лабораторних умовах та передбачав проведення полімеразно-ланцюгової реакції з ідентифікацією кількості умовно-патогенних мікроорганізмів у режимі реального часу.

Результати досліджень та їх обговорення. Проведений аналіз виявив наступні середні показники кількості ключових пародонтопатогенів у мазках зубного нальоту з ділянки зубоясенної боріздки серед пацієнтів із І стадією розвитку пародонтиту: P. gingivalis - $(5,4 \pm 0,3) \mathrm{Lg}$ (ГЕ/зразок), Т. forsythia - $(5,1 \pm 0,2) \mathrm{Lg}$ (ГЕ/зразок), P. intermedia - $(5,0 \pm 0,5) \mathrm{Lg}(Г Е / з$ разок), T. denticola - $(3,9 \pm 0,7) \mathrm{Lg}(\Gamma \mathrm{L} /$ зразок). При цьому показник загальної бактеріальної маси складав $(6,7 \pm 0,4) \mathrm{Lg}($ ГЕ/зразок).

Висновки. Виходячи із отриманих даних можна констатувати факт статистично значимого зростання кількості усіх дослідних мікроорганізмів при I стадії пародонтиту, порівняно з показниками, котрі були зареєстровані серед осіб контрольної групи без клінічновиражених ознак ураження тканин пародонта $(\mathrm{p}<0,05)$. Подальші дослідження повинні бути спрямовані на модифікацію існуючих протоколів лікування пародонтальних уражень шляхом їх індивідуалізації з урахуванням зареєстрованих змін мікробіологічного профілю. 
Вступ. Оновлені дані щодо поширеності пародонтиту на території США за інформаці$€ ю$ National Health and Nutrition Examination Survey (NHANES) свідчать, що близько $42 \%$ населення (64,7 млн осіб) у віці більше 30 років характеризується наявністю різних форм пародонтальних уражень, при цьому майже у 7,8 \% населення було зареєстровано саме найважчу стадію пародонтиту [1]. У свою чергу, епідеміологічна ситуація щодо поширеності пародонтиту в Україні характеризується чітко вираженою тенденцією до зростання кількості зареєстрованих випадків ураження упродовж останніх десяти років та підвищенням частоти випадків діагностики патології серед стоматологічних пацієнтів із віком [2, 3]. У дослідженні F. Romano et all. (2019) було відмічено, що використання існуючих на сьогодні протоколів пародонтальної діагностики характеризується значним рівнем ризику виникнення похибок реєстрації, які, у свою чергу, провокують заниження дійсних показників поширеності патології на 8,9-15,5 \% [4].

Виникнення пародонтиту доказово асоційоване із впливом специфічних видів мікроорганізмів, категоризованих у відповідні комплекси, проте характер перебігу патології та ефективність лікування визначаються складною взаємодією між патогенетичними факторами та індивідуальними генетичними, імунологічними та бактеріологічними пацієнтасоційованими параметрами [5, 6]. 3апальна відповідь на інвазію та вплив мікроорганізмів, асоційованих із пародонтальним ураженням, являє собою каскад комплексних та мультифакторних реакцій, які в результаті впливають на клінічний характер перебігу захворювання. Результати попередніх досліджень вказують на існування залежності між інтенсивністю та тривалістю запальних проявів пародонтиту й особливостями структури природного мікробіома ротової порожнини та його змінами в результаті спровокованого дизбіозу [6-9].

Ідентифікація кількісних відмінностей у структурі мікробіома порожнини рота за умов норми та патології дозволяє виокремити найбільш значущі аспекти патогенезу, направлена дія на котрі сприятиме клінічному одужанню пацієнта. Механізм лікувального ефекту в окремих випадках може передбачати не тільки елімінацію чи зниження концентрації специфічних пародонтопатогенів, а й нормалізацію складу мікробіома в цілому та досягнення специфічних кількісних співвідношень між цільовими видами мікроорганізмів [5-7].

Враховуючи таку роль у змінах бактеріологічного профілю ротової порожнини в розвитку пародонтиту, актуальним для вивчення на сьогодні залишається аспект порівняльного аналізу особливостей мікробіоценозу в умовах норми та на різних стадіях патології для верифікації специфічних змін співвідношень окремих мікробіологічних комплексів між собою. Такий підхід сприятиме індивідуалізації протоколів лікування стоматологічних пацієнтів та імплементації принципів персоналізованої медицини в стоматологічну практику.

Метою дослідження було встановити середні показники кількості основних пародонтопатогенів у складі мазків зубного нальоту 3 ділянки зубоясенної боріздки із І стадією пародонтиту.

Матеріали і методи. У ході реалізації поставленої мети були сформовані дослідна та контрольна групи осіб. До складу дослідної групи було включено 19 осіб із І стадією пародонтиту. Вікових чи гендерних критеріїв при формуванні контрольної чи дослідної груп осіб не застосовували. Оцінку стадії пародонтиту проводили згідно з рекомендаціями American Academy of Periodontology від 2017 р., відповідно до якої для I стадії пародонтиту характерно: втрата рівня зубоясенного прикріплення між зубами в межах 1-2 мм, максимальна глибина пародонтальних кишень до 4 мм, переважно горизонтальний тип втрати кісткової тканини, та рентгенологічний рівень втрати кістки не більш ніж на 15 \% довжини кореня [10]. Вищеописані параметри використовували в якості критеріїв включення при формуванні дослідної групи осіб. До складу контрольної групи було включено 17 осіб без клінічно зареєстрованих ознак ураження тканин пародонта.

Визначення кількісного складу цільових пародонтопатогенів в умовах норми та I стадії розвитку пародонтиту проводили із застосуванням аналізу «Пародонтоскрин». Даний аналіз виконували в лабораторних умовах та передбачав проведення полімеразно-ланцюгової реакції (ПЛР) з ідентифікацію кількості умовнопатогенних мікроорганізмів у режимі реального часу. Суть дослідження полягала у виділенні ДНК мікроорганізмів та ПЛР-ампліфікації ДНК 3 використанням набору реагентів. В якості досліджуваного матеріалу використовували мазки зубного нальоту з ділянки зубоясенної 
боріздки жувальної групи зубів. Інтерпретацію результатів щодо ступеня патології залежно від кількості зареєстрованих мікроорганізмів кожного виду проводили відповідно до лабораторних рекомендацій, які визначали наступні граничні рівні показників між станом норми та легким/середнім ступенем пародонтиту: Porphyromonas gingivalis (P. gingivalis) - 6,5 Lg (ГЕ/зразок); Tannerella forsythensis (T. forsythia) - 5,0 Lg (ГЕ/зразок); Prevotella intermedia (P. Intermedia) - 4,5 Lg (ГЕ/зразок); Treponema denticola (T. denticola) - 3,5 Lg (ГЕ/зразок).

Групування, категоризацію та статистичне опрацювання результатів дослідження проводили у програмному забезпеченні Microsoft Excel 2019, що входить до складу пакета програмного забезпечення Microsoft Office 2019 (Microsoft).

Результати досліджень та їх обговорення. Принципи персоналізованої медицини передбачають проведення індивідуально-орієнтованого лікування з урахуванням генетичних, протеомних та клінічних особливостей кожного окремого пацієнта. Такий підхід обгрунтований поліфакторною природою більшості захворювань, у тому числі й стоматологічних, ефективна терапія котрих включає реалізацію низки ятрогенних втручань, направлених на різні складові патологічного процесу [11-13]. Крім того, врахування імунологічних, генетичних та мікробіологічних особливостей пацієнта сприяє не тільки успішному лікуванню, а й підвищенню ефективності етапів діагностики та профілактики. Диференційований вибір діючого медикаментозного засобу або ж методу лікування залежно від особливостей встановлених імунологічного, генетичного та протеомного профілів передбачає формування можливостей не тільки для оптимізації алгоритму лікування, а й умов для мінімізації ризиків виникнення ускладнень та побічних ефектів [12-14].

Алгоритм реалізації принципів персоналізованої медицини при лікуванні пародонтальних уражень передбачає: 1) забір біологічного матеріалу та формування бактеріальних зразків із різних ділянок ротової порожнини для оцінки якісного та кількісного складу кожної із них з формуванням відповідних профілів; 2) аналіз метагеномного, протеомного та метаболічного профілів пацієнта із застосування методів генотипування; 3) збір інформації щодо клінічного перебігу захворювання, анамнезу та впливу факторів середовища; 4) форму- вання реєстру біобанку даних; 5) статистичне моделювання патернів впливу різних медикаментозних засобів, методів лікування та їх комбінації на результат втручання виходячи із аналізу первинно зібраних даних; 6) реалізацію того чи іншого терапевтичного підходу, який за результатами моделювання характеризувався найвищим рівнем ефективності [11, 14]. Крім того, при дослідженні вищезгаданих профілів пацієнтів важливо забезпечити аналіз їх змін залежно від існуючої клінічної картини перебігу пародонтальної патології.

Вихідні середні параметри оцінки пародонтологічного статусу серед пацієнтів групи дослідження були представлені наступним чином: середній показник глибини пародонтального зондування складав $(3,2 \pm 0,6) \mathrm{Mм}$, середній показник втрати рівня клінічного прикріплення між зубами - $(1,5 \pm 0,7)$ мм, кровоточивість при зондуванні була виявлена в 47,36 \% випадків. У контрольній групі серед пацієнтів без клінічно-видимих ознак пародонтального ураження середня глибина пародонтального зондування складала $(1,5 \pm 0,6)$ мм, а середній рівень втрати клінічного прикріплення між зубами - $(0,8 \pm 0,6)$ мм, при цьому кровоточивість при зондуванні була відмічена у 11,7 \% обстежуваних осіб.

Проведений пародонтискрин виявив наступні середні показники кількості ключових пародонтопатогенів у мазках, взятих із ділянки зубних відкладень серед пацієнтів із I стадією розвитку пародонтиту: P. gingivalis -

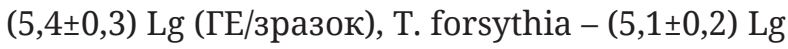
(ГЕ/зразок), P. intermedia - $(5,0 \pm 0,5)$ Lg (ГЕ/зразок), T. denticola - $(3,9 \pm 0,7)$ Lg (ГЕ/зразок). При цьому показник загальної бактеріальної маси

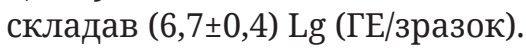

У клінічно здорових пацієнтів без зареєстрованих ознак пародонтиту був зареєстрований наступний розподіл показників кількості пародонтопатогенів у складі мазків, отриманих із ділянки зубних відкладень: P. gingivalis -

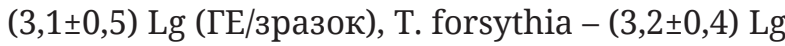

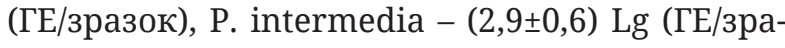
зок), T. denticola - $(2,4 \pm 0,9)$ Lg (ГЕ/зразок). При цьому показник загальної бактеріальної маси складав $(4,8 \pm 0,7)$ Lg (ГЕ/зразок). Статистично значима різниця показників кількості основних пародонтопатогенів, виявлених серед здорових осіб та осіб із І стадією розвитку пародонтиту, згідно з критеріями ААР була ідентифікована при аналізі усіх дослідних мікроорганізмів $(\mathrm{p}<0,05)$. 
Встановлений факт статистично підтверджених змін кількості специфічних пародонтопатогенів в умовах норми та пародонтиту I стадії слугує достатнім підгрунтям для подальшого вивчення даних варіацій залежно від обраного методу лікування уражень тканин пародонта. Проте необхідно пам'ятати, що патерн розвитку та прогресування пародонтальної патології залежить не тільки від безпосереднього впливу факторів концентрації та активності основних пародонтальних патогенів, але й від особливостей імунної відповіді організму, детермінованих пацієнтспецифічними умовами ротової порожнини як біологічного середовища [14].

У ході попередньо проведених метагеномних досліджень було доведено факт значущої варіативності мікробіома ротової порожнини між різними дослідними індивідами, що навіть за умов однакових патологій аргументує доцільність модифікації та персоналізації стандартних алгоритмів лікування [14].

Попередньо в літературі було описано спосіб прогнозування ймовірності виникнення запальних пародонтальних уражень з урахуванням змін мікробіологічного профілю, запропонований В. В. Чередою та співавт. (2015). Дослідники описали метод використання кількісних показників коків, паличкоподібних мікроорганізмів та звивистих форм із метою визначення коефіцієнта сталості мікрофлори, адгезивного індексу та показника колонізаційної резистентності відповідно до спеціально розробленої формули [15]. Такий підхід також можна категоризувати як аспект індивідуалізації діагностичної складової, що в цілому сприяє підвищенню рівня профілактики пародонтологічних захворювань, виходячи з аналізу змін мікробіологічного профілю.

Особливості змін мікробіоценозу пародонтальних кишень при супутньому впливі інших провокуючих факторів були описані у дослідженні О. О. Фастовець та В. Г. Малиновського (2018). Автори довели, що наявність оклюзійних розладів у пацієнтів, хворих на генералізований пародонтит, провокує зменшення кількості пародонтопротекторних мікроорганізмів та зростання кількості представників умовно-патогенної мікрофлори [16]. Зокрема дослідники виявили статично підтверджене зростання кількості таких бактерій як Str. salivarius, Str. sanguis та Str. mitis y структурі пародонтальних кишень [16].
Базуючись на змінах кількості пародонтопатогенів, зареєстрованих за допомогою лабораторних методів дослідження, О. Н. Васеніна та співавт. (2018) змогли експериментально обгрунтувати доцільність використання мелатоніну в ході лікування хронічного генералізованого пародонтиту [17].

Крім змін власне структури мікробіома ротової порожнини, значу роль у розвитку пародонтиту відіграють також параметри генетичного профілю пацієнта. Залежно дії функції ключових генів, які забезпечують кодування білків (цитокінів, ензимів, клітинної активації, адгезіі), та рівня генетичних варіацій, вираження клінічних проявів пародонтиту може відрізнятися у різних індивідів. Результати окремих досліджень вказують навіть на потенційну відмінність у кількості генів, що відповідають за модифікацію клінічного перебігу пародонтиту [14]. Відмінність генетичного профілю між індивідами також може бути асоційованою із варіативністю клінічних проявів пародонтиту в формі різних рівнів втрати клінічного прикріплення, кровоточивості, резорбції кістки, розмірів пародонтальних кишень.

Таким чином, в ході проведеного дослідження було встановлено факт наявності статистично підтверджених змін кількості специфічних пародонтопатогенів в умовах норми та пародонтиту I стадії. Зіставлення отриманих результатів із даними, представленими у попередніх дослідженнях, свідчить про доцільність подальшого вивчення взаємозв'язків між параметрами клінічного перебігу пародонтиту та кількісними варіаціями у структурі мікробіологічного профілю ротової порожнини з метою індивідуалізації існуючих протоколів лікування.

Висновки. У результаті проведеного дослідження було встановлено середні показники кількості ключових пародонтопатогенів у мазках, взятих із ділянки зубних відкладень серед пацієнтів з I стадією розвитку пародонтиту: P. gingivalis - $(5,4 \pm 0,3) \mathrm{Lg}$ (ГЕ/зразок), T. forsythia $-(5,1 \pm 0,2) \mathrm{Lg}$ (ГЕ/зразок), P. intermedia - $(5,0 \pm 0,5)$ Lg (ГЕ/зразок), T. denticola - $(3,9 \pm 0,7)$ Lg (ГЕ/зразок). Виходячи із отриманих даних, можна констатувати факт статистично значимого зростання кількості усіх дослідних мікроорганізмів при I стадії пародонтиту, порівняно $з$ показниками, котрі були зареєстровані серед осіб контрольної групи без клінічновиражених ознак ураження тканин пародонта 
$(\mathrm{p}<0,05)$. Подальші дослідження повинні бути спрямовані на модифікацію існуючих протоколів лікування пародонтальних уражень шляхом їх індивідуалізації з урахуванням зареєстрованих змін мікробіологічного профілю. Протокол персоналізованого пародонтолікування повинен передбачати можливості для ідентифікації найбільш потенційно успішного медикаментозного засобу та його дози, що характеризуватиметься контрольованим та ефективним впливом на різні фенотипи мікроорганізмів, які, у свою чергу, можуть відрізнятися рівнями чутливості та резистентності до антибіотиків та антисептиків.

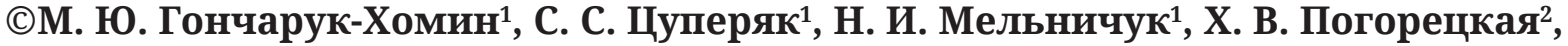 Л. А. Пацкань}

ДВНЗ «Ужгородский национальный университет»

Тернопольский национальный медицинский университет

имени И. Я. Горбачевского МОЗ Украины²

\section{Оценка количественных изменений микробиологического профиля зубного налёта области зубодёсневой бороздки в пациентов с I стадией пародонтита}

Резюме. Возникновение пародонтита доказательно ассоциированно с влиянием специфических видов микроорганизмов, категоризированных в соответствующие комплексы, однако характер протекания патологии и эффективность лечения определяются сложным взаимодействием между патогенетическими факторами и индивидуальными генетическими, иммунологическими и бактериологическими пациентассоциированными параметрами.

Цель исследования - установить средние показатели количества основных пародонтопатогенов в составе мазков зубного налета у пациентов с I стадией пародонтита.

Материалы и методы. В ходе реализации поставленной цели были сформированы исследуемая и контрольная группы пациентов. В состав исследуемой группы были включены 19 человек с I стадией пародонтита, в состав контрольной - 17 человек без клинически зарегистрированных признаков поражения тканей пародонта. Оценка стадии пародонтита проводилась согласно рекомендациям American Academy of Periodontology от 2017 г. Определение количественного состава целевых пародонтопатогенов в условиях нормы и I стадии развития пародонтита проводили с применением анализа «Пародонтоскрин», который выполнялся в лабораторных условиях и предусматривал проведение полимеразной цепной реакции с идентификацией количества условно-патогенных микроорганизмов в режиме реального времени.

Результаты исследований и их обсуждение. Проведенный анализ выявил следующие средние показатели количества ключевых пародонтопатогенов в мазках, взятых из области зубных отложений среди больных с I стадией развития пародонтита: P. gingivalis - $(5,4 \pm 0,3) \mathrm{Lg}$ (ГЭ/образец), T. forsythia -

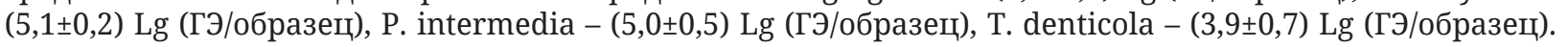
При этом показатель общей бактериальной массы составлял $(6,7 \pm 0,4) \mathrm{Lg}$ (ГЭ/образец).

Выводы. Исходя из полученных данных, можно констатировать факт статистически значимого роста количества всех исследуемых микроорганизмов при I стадии пародонтита, по сравнению с показателями, которые были зарегистрированы среди лиц контрольной группы без клинически выраженных признаков поражения тканей пародонта (p<0,05). Дальнейшие исследования должны быть направлены на модификацию существующих протоколов лечения пародонтальных поражений путем их индивидуализации с учетом зарегистрированных изменений микробиологического профиля.

Ключевые слова: пародонтит; пародонтопатогены; лабораторный анализ. 


\author{
(c)M. Y. Goncharuk-Khomyn ${ }^{1}$, S. S. Tsuperyak ${ }^{1}$, N. I. Melnychuk ${ }^{1}$, Kh. V. Pohoretska ${ }^{2}$, \\ L. O. Patskan ${ }^{2}$ \\ Uzhhorod National University ${ }^{1}$ \\ Horbachevsky Ternopil National Medical University²
}

\title{
Microbiological profile quantitative changes evaluation among patients with stage I periodontitis
}

\begin{abstract}
Summary. Periodontitis occurence evidenced by the influence of specific types of microorganisms categorized into appropriate complexes, but the nature of the pathology and the effectiveness of treatment are determined by the complex interaction between pathogenetic factors and individual genetic, immunological and bacteriological parameters.

The aim of the study - to establish average quantitative indicators of major periodontal pathogens in plaque smears of patients with stage I periodontitis.

Materials and Methods. Study and control groups of patients were formed in order to achieve the aim of the research. The study group included 19 persons with stage I periodontitis, while control group included 17 persons without clinically registered signs of periodontal tissue damage. The periodontitis stage was evaluated according to the recommendations of the American Academy of Periodontology proposed in 2017. The quantitative evaluation of target periodontal pathogens during normal conditions and during stage I periodontitis was performed using "Parodontoscreen" analysis, which was performed under laboratory conditions and included provision of polymerase-chain reaction to identify the number of opportunistic microorganisms in real time.

Results and Discussion. The analysis revealed the following average quantitative indicators of key periodontal pathogens in smears taken from the dental plaque among patients with stage I periodontitis: P. gingivalis -

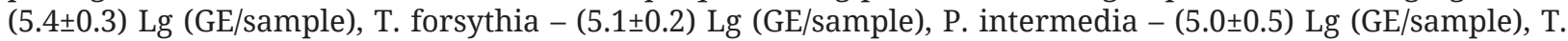

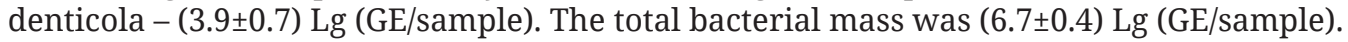

Conclusions. Based on the data obtained, it can be stated that there is a statistically significant increase in the number of all tested microorganisms during stage I periodontitis compared to the indicators that were registered among the control group patients without clinically expressed signs of periodontal tissue damage $(p<0.05)$. Further studies should aimed at the modification of existing periodontal treatment protocols by their individualization, taking into account the recorded changes in the microbiological profile.
\end{abstract}

Key words: periodontitis; periodontal pathogens; laboratory analysis.

\section{СПИСОК ЛІТЕРАТУРИ}

1. Update on prevalence of periodontitis in adults in the United States: NHANES 2009 to 2012 / P. I. Eke, B. A. Dye, L. Wei [et al.] // Journal of Periodontology. 2018. - No. 86 (5). - P. 611-622.

2. Малий д. Ю. Епідеміологія захворювань пародонта: віковий аспект / Д. Ю. Малий, М. Ю. Антоненко // Український науково-медичний молодіжний журнал. - 2013. - № 4. - С. 41-43.

3. Казакова Р. В. Порівняльний аналіз показників карієсу зубів і захворювань тканин пародонта у підлітків, які проживають у різних екологічних умовах / Р. В. Казакова, В. С. Мельник, М. В. Білищук // Новини стоматології. - 2013. - № 1. - С. 78-79. 4. Prevalence of periodontitis: misclassification, underrecognition or over-diagnosis using partial and fullmouth periodontal examination protocols / F. Romano, S. Perotto, A. Castiglione [et al.] // Acta Odontologica Scandinavica. - 2019. - No. 77 (3). - P. 189-196.

5. Taylor J. J. A review of the evidence for pathogenic mechanisms that may link periodontitis and diabetes / J. J. Taylor, P. M. Preshaw, E. Lalla // Journal of Clinical Periodontology. - 2013. - No. 40. - P. S113-S134.

6. Hajishengallis G. Periodontitis: from microbial immune subversion to systemic inflammation /
G. Hajishengallis // Nature Reviews Immunology. - 2015. - No. 15 (1). - P. 30.

7. Relationship between oral microbiota and periodontal disease: A systematic review / R. Patini, E. Staderini, C. Lajolo [et al.] // Eur. Rev. Med. Pharmacol. Sci. - 2018. - No. 22. - P. 5775-5788.

8. Ari G. Epigenetics and periodontitis: a contemporary review / G. Ari, S. Cherukuri, A. Namasivayam // Journal of Clinical and Diagnostic Research: JCDR. - 2016. No. 10 (11). - P. ZE07.

9. Microbial profiles at baseline and not the use of antibiotics determine the clinical outcome of the treatment of chronic periodontitis / S. Bizzarro, M. L. Laine, M. J. Buijs // Scientific Reports. - 2016. No. 6. - P. 20205.

10. Tonetti M. S. Staging and grading of periodontitis: Framework and proposal of a new classification and case definition / M. S. Tonetti, H. Greenwell, K. S. Kornman // Journal of Clinical Periodontology. 2018. - No. 45. - P. S149-S161.

11. Personalized medicine in dentistry/P.S. Pudakalkatti, A. S. Baheti, S. A. Hattarki [et al.] // Journal of Orofacial Sciences. - 2017. - No. 9 (1). - P. 3.

12. Kornman K. S. Personalized medicine: will dentistry 
ride the wave or watch from the beach? / K. S. Kornman, G. W. Duff // Journal of Dental Research. - 2012. - No. 91 (7 suppl.). - P. S8-S11.

13. Garcia I. Expanding the foundation for personalized medicine: implications and challenges for dentistry / I. Garcia, R. Kuska, M. J. Somerman // Journal of Dental Research. - 2013. - No. 92 (7 suppl.). - P. S3-S10.

14. Razzouk S. Host genome, epigenome, and oral microbiome interactions: toward personalized periodontal therapy / S. Razzouk, O. Termechi // Journal of Periodontology. - 2013. - No. 84 (9). - P. 1266-1271. 15. Череда В. В. Оцінка ризику запальних захворювань пародонта / В. В Череда, Т. О. Петрушанко,

\section{REFERENCES}

1. Eke, P.I., Dye, B.A., Wei, L., Slade, G.D., Thornton Evans, G.O., Borgnakke, W.S., ... \& Genco, R.J. (2015). Update on prevalence of periodontitis in adults in the United States: NHANES 2009 to 2012. Journal of Periodontology, 86 (5), 611-622.

2. Malyi, D.Yu., \& Antonenko, M.Yu. (2013). Epidemiolohiia zakhvoriuvan parodonta: vikovyi aspect [Disease epidemiology periodontitis: age aspect]. Ukrainskyi naukovo-medychnyi molodizhnyi zhurnal - Ukrainian Scientific Medical Youth Journal, (4), 41-43 [in Ukrainian].

3. Kazakova, R.V., Melnyk, V.S., \& Bilyshchuk, M.V. (2013). Porivnialnyi analiz pokaznukiv kariiesu i zahvoriuvan parodonta u pidlitkiv, yaki prozhyvaiut $\mathrm{u}$ riznykh ekolohichnykh umovakh [Comparative analysis of prevalence and intensity of caries and diseases of parodontitis in teenagers living in different ecological conditions]. Novyny Stomatolohii - News of Dentistry, (1), 78-79 [in Ukrainian].

4. Romano, F., Perotto, S., Castiglione, A., \& Aimetti, M. (2019). Prevalence of periodontitis: misclassification, under-recognition or over-diagnosis using partial and full-mouth periodontal examination protocols. Acta Odontologica Scandinavica, 77 (3), 189-196.

5. Taylor, J.J., Preshaw, P.M., \& Lalla, E. (2013). A review of the evidence for pathogenic mechanisms that may link periodontitis and diabetes. Journal of Clinical Periodontology, 40, S113-S134.

6. Hajishengallis, G. (2015). Periodontitis: from microbial immune subversion to systemic inflammation. Nature Reviews Immunology, 15 (1), 30.

7. Patini, R., Staderini, E., Lajolo, C., Lopetuso, L., Mohammed, H., Rimondini, L., ... \& Gallenzi, P. (2018). Relationship between oral microbiota and periodontal disease: A systematic review. Eur. Rev. Med. Pharmacol. Sci., 22, 5775-5788.

8. Ari, G., Cherukuri, S., \& Namasivayam, A. (2016). Epigenetics and periodontitis: a contemporary review. Journal of Clinical and Diagnostic Research: JCDR, 10 (11), ZE07.

9. Bizzarro, S., Laine, M.L., Buijs, M.J., Brandt, B.W., Crielaard, W., Loos, B. G., \& Zaura, E. (2016). Microbial profiles at baseline and not the use of antibiotics
Г. А. Лобань // Вісник стоматології. - 2011. - № 4. C. 29-31.

16. Фастовець О. О. Особливості мікробіоценозу пародонтальних кишень у хворих на генералізований пародонтит при оклюзійному дисбалансі / О. О. Фастовець, В. Г. Малиновський // Вісник морської медицини. - 2018. - № 4. - С. 50-55.

17. Экспериментальное обоснование применения мелатонина в терапии хронического генерализованого пародонтита / О. Н. Васенина, С Н. Громова,

Е. П. Колеватых, Е. К. Кропанева // Вятский медицинский вестник. - 2018. - № 57. - С. 13-16.

determine the clinical outcome of the treatment of chronic periodontitis. Scientific Reports, 6, 20205.

10. Tonetti, M.S., Greenwell, H., \& Kornman, K.S. (2018). Staging and grading of periodontitis: Framework and proposal of a new classification and case definition. Journal of Clinical Periodontology, 45, S149-S161.

11. Pudakalkatti, P.S., Baheti, A.S., Hattarki, S.A., \& Kambali, S.S. (2017). Personalized medicine in dentistry. Journal of Orofacial Sciences, 9 (1), 3.

12. Kornman, K.S., \& Duff, G.W. (2012). Personalized medicine: will dentistry ride the wave or watch from the beach? Journal of Dental Research, 91 (7 suppl), S8S11.

13. Garcia, I., Kuska, R., \& Somerman, M.J. (2013). Expanding the foundation for personalized medicine: implications and challenges for dentistry. Journal of Dental Research, 92 (7 suppl.), S3-S10.

14. Razzouk, S., \& Termechi, O. (2013). Host genome, epigenome, and oral microbiome interactions: toward personalized periodontal therapy. Journal of Periodontology, 84 (9), 1266-1271.

15. Chereda, V.V., Petrushanko, T.O., \& Loban, G.A. (2011). Otsinka ryzyku zapalnykh zahvoriuvan parodonta [The estimation of the risk of inflammatory diseases of periodontium]. Visnyk Stomatolohii-Bulletin of Dentistry, 4, 29-31 [in Ukrainian].

16. Fastovets, O.O., \& Malynovskyi, V.H., (2018). Osoblyvosti microbiotsenozu parodontalnykh kyshen $\mathrm{u}$ hvorykh na heneralizovanyi parodontyt pry okluziinomu dysbalansi [Pecularities of microbiocenosis of periodontal pockets in patients with generalized periodontits under occlusal disbalance]. Visnyk morskoi medysyny - Bulletin of Maritime Medicine, 4, 50-55 [in Ukrainian].

17. Vasenina, O.N., Gromova, S.N., Kolevatykh, E.P., \& Kropaneva, E.K. (2018). Eksperimentalnoe obosnovanie primineniya melatonina $\mathrm{v}$ terapii generalizirovanoho parodontita [Experimental validation of applying melatonin in the treatment for chronic generalized periodontits]. Vyatskiy meditsinskiy vestnik - Medical Newsletter of Vyatka, 57, 13-16 [in Russian]. 